\title{
The Swedish-Speaking Population on the Finnish Labor Market
}

\author{
FJALAR FINNÄS, Ph.D., Research Director \\ Institutet för finlandssvensk samhällsforskning \\ Åbo Akademi University, Vaasa, Finland
}

\begin{abstract}
The Swedish-speaking population in Finland constitutes a linguistic minority in numbers, but has equal constitutional rights with the Finnish-speaking majority. In the 19th century, Swedish was the dominant language of government, business and culture. At present, though, the two language groups have almost the same distributions by industry and socioeconomic position at the national level. Generally, the differences between regions are wider than between the two language groups. The labor force participation rate is also very much the same. The unemployment rate, however, is clearly lower among Swedish speakers and retirement at an early age (i.e. disability pension) less common. These disparities remain also after a great number of background variables have been controlled for.
\end{abstract}

Keywords: language groups, socioeconomic position, labor force participation, unemployment

\section{Introduction}

The traditional view of the labor market suggests that minority groups are discriminated against (Becker 1957). In practice, most empirical studies on the position and success of ethnic minorities on the labor market have been concerned with immigrants, and have proved this to be true (see e.g. Chiswick 1977, 1978; Borjas 1993, 1994). Some ethnic minorities, however, manage well, and have a relatively strong position on the labor market. One example of this is the Welsh speakers in Wales. Drinkwater and O'Leary (1997) show that the unemployment propensity of the Welsh speakers is lower than that of those speaking English only. Other examples are American-born Chinese, Japanese and Jews in the U.S. labor market (Brenner and Kiefer 
1981 ; Sowell 1981; Chiswick 1983a 1983b). However, an ethnic minority is not necessarily composed of first- or second-generation immigrants. It can also be a native minority with a long history in the country. In this paper I will focus on a native ethnic minority which also manages well, namely the Swedish-speaking population in Finland.

The roots of the Swedish-speaking population go far back in history to when Finland was a part of the realm of Sweden. Swedish was then the dominant language of government, business and culture. When Finland became a part of the Russian Empire in 1809 , the Swedish-speaking population constituted a 15 percent minority, but it was not until the late 19th century that the Finnish language achieved equal status with Swedish.

According to the Constitution Act Finnish and Swedish have equal status as official languages. This means that the Swedish-speaking minority is guaranteed constitutional rights. It is also covered by a considerable organizational and institutional network. For example, parallel to the Finnish schooling system there is another one with the same curriculum, but with all instruction given in Swedish. The Swedish schooling system covers all basic education, and also most fields at the secondary level. Additionally, there is one university, Abo Akademi University, with all instruction given in Swedish. At the University of Helsinki there are also a certain number of Swedish-speaking professors. Moreover, there is a diocese for all Swedish-language parishes in the Evangelical Lutheran church. Besides their importance as elements of the Swedish-speaking community in Finland, these institutions and organizations offer a considerable number of job opportunities for Swedish speakers.

In order to understand the position of the Swedish-speaking population, one must look at the development of its spatial distribution and concentration. In the late 19th century, the two language groups lived almost separated from each other. Very few of the Swedish speakers lived in the interior of the country but they almost totally dominated the regions along the western and southern coastlines. In 1880 some 85 percent of the 294,900 Swedish speakers lived in municipalities where their proportion of the total population was more than two-thirds. At the national level the proportion of Swedish speakers was 14.3 percent.

The number of Swedish speakers increased to 354,000 in 1940, but it decreased dramatically during the following decades, mainly due to migration to Sweden. Since 1970, the decrease has been moderate. At present, the number of Swedish speakers, which was 290,700 at the end of 2001, is thus about the same as in 1880 . However, since the Finnish-speaking population has more than doubled in the same period, and now amounts to almost 4.8 million persons, the proportion of the total population composed by Swedish speakers is only 5.6\%. Due to the fact that the southern part of the Swedish settlement area is a region that has witnessed great in-migration from other parts of the country, the changes at the local level have been much more dra- 
matic. The Swedish-speaking population has become a small minority in this area. Almost half of the Swedish speakers still live in municipalities where they outnumber the Finnish speakers. The map in Figure 1 illustrates the Swedish and bilingual area in Finland.

It is also worth pointing out that both previously and at present the Swedish-speaking population has lived in both the center and the periphery of the country, and that it is not restricted to any certain social class.

In this paper, I will focus on some aspects of the performance and position of the Swedish-speaking population on the labor market in Finland. I start by looking at the distribution by industry and the socioeconomic position of economically active persons, and continue with some comments about labor force participation, unemployment and retirement. The paper is also an illustration of how the empirical findings may depend on what regions one focuses on. The entire study is based on registered data provided by Statistics Finland.

Figure 1. The Swedish and bilingual municipalities in Finland.

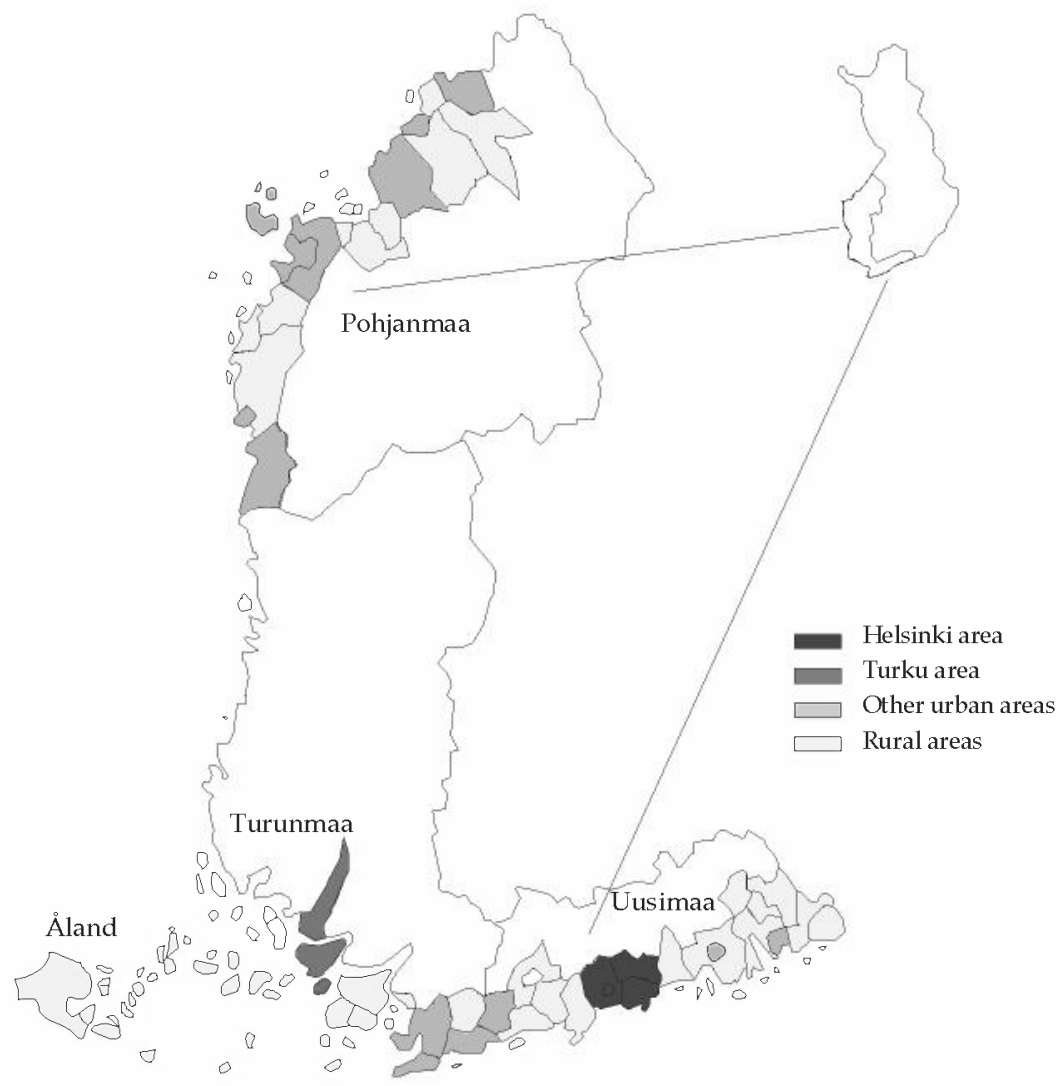




\section{Industry of the economically active population}

As pointed out previously, the Swedish-speaking population is not restricted to any certain social class, and it has lived in both urban and rural areas. Therefore, the distribution by industry of the economically active persons has been very much the same among the Swedish speakers as among the Finnish-speaking majority during the last few decades (Table 1). The only distinct differences are that the proportion employed in manufacturing has been lower among Swedish speakers and correspondingly higher in the transport sector. In both language groups, the service sector has grown rapidly, which corresponds to a decrease in agriculture and manufacturing. Among the Swedish speakers, the decrease of the agriculture sector seems to be somewhat smaller than among the rest of the population.

Table 1 . The distribution by industry of the economically active population in 1970 , 1980 and 1995 for Finnish speakers and Swedish speakers. Entire country, \%.

\begin{tabular}{ccccccccc}
\hline & $\begin{array}{c}\text { Agricul- } \\
\text { ture }\end{array}$ & $\begin{array}{c}\text { Manu- } \\
\text { facturing }\end{array}$ & Trade & Transport & $\begin{array}{c}\text { Finan- } \\
\text { cing }\end{array}$ & Service & Unknown Total \% \\
\hline $\begin{array}{l}\text { Finnish } \\
\text { speakers }\end{array}$ & & & & & & & & \\
1970 & 20.3 & 34.7 & 15.3 & 6.9 & 3.3 & 18.1 & 1.4 & 100 \\
1980 & 12.7 & 34.3 & 14.0 & 7.9 & 5.4 & 25.3 & 0.3 & 100 \\
1995 & 6.9 & 26.9 & 14.4 & 7.3 & 11.1 & 31.1 & 2.3 & 100 \\
& & & & & & & & \\
Swedish & & & & & & & & \\
speakers & & & & & & & & \\
1970 & 19.4 & 29.3 & 17.6 & 9.9 & 4.5 & 18.0 & 1.3 & 100 \\
1980 & 14.9 & 27.1 & 15.9 & 10.7 & 6.5 & 24.4 & 0.4 & 100 \\
1995 & 9.1 & 20.9 & 15.4 & 10.1 & 10.5 & 31.3 & 2.8 & 100 \\
\hline
\end{tabular}

The great similarities between the language groups are still somewhat surprising, considering that regional differences exist in Finland and that the Swedish-speaking population is concentrated in only a small part of the country. It therefore may seem more correct to restrict the study to the main Swedish-settlement area. About 95 percent of all Swedish speakers live in the unilingual Swedish or bilingual municipalities. A restriction to these municipalities changes the results for the Swedish speakers only marginally, whereas there are some interesting effects on the distribution for the Finnish speakers (Table 2).

Due to the fact that these areas previously were almost totally dominated by Swedish speakers, there are still very few Finnish-speaking landowners and farmers. Of all farmers in these municipalities less than $20 \%$ were Finnish speaking in 1995 . The relatively high proportion of Finnish speakers in the finance sector is partly due to the regional distribution of the population. More than two-thirds of the Finnish speakers 
in these municipalities live in the Metropolitan Area. I will return to this when I look at the distribution by socioeconomic position.

Table 2. The distribution by industry of the economically active population in 1970, 1980 and 1995 for Finnish speakers and Swedish speakers. Unilingual Swedish and bilingual municipalities.

\begin{tabular}{lcccccccc}
\hline & $\begin{array}{c}\text { Agricul- } \\
\text { ture }\end{array}$ & $\begin{array}{c}\text { Manu- } \\
\text { facturing }\end{array}$ & Trade & Transport Financing & Service & Unknown & Total \% \\
\hline $\begin{array}{l}\text { Finnish } \\
\text { speakers }\end{array}$ & & & & & & & & \\
1970 & 1.7 & 36.9 & 20.5 & 7.8 & 7.2 & 24.6 & 1.3 & 100 \\
1980 & 1.3 & 30.1 & 18.7 & 9.3 & 10.5 & 29.7 & 0.5 & 100 \\
1995 & 0.7 & 21.1 & 17.8 & 8.5 & 16.7 & 33.1 & 2.0 & 100 \\
& & & & & & & & \\
Swedish & & & & & & & & \\
speakers & & & & & & & & \\
1970 & 19.7 & 28.8 & 17.7 & 9.9 & 4.6 & 18.0 & 1.3 & 100 \\
1980 & 14.3 & 26.7 & 16.2 & 11.0 & 6.7 & 24.8 & 0.4 & 100 \\
1995 & 9.2 & 20.6 & 15.3 & 10.2 & 10.5 & 31.3 & 2.8 & 100 \\
\hline
\end{tabular}

On the one hand, these two tables show that at the national level the distributions by industry are very much the same. On the other hand there are clear differences at the local level. An investigation of a more detailed industry classification also offers some interesting observations. Since the Swedish speakers live along the coast, it is natural that they are employed in fishing and transport at sea to a greater extent than the Finnish speakers. Thus, of all persons employed in these sectors about one-third are Swedish speaking. On the other hand, relatively few Swedish speakers are employed in, for instance, defence (3.8\%), information technology (4.1\%), manufacturing and the hotel sector (both $4.5 \%$ ).

\section{Socioeconomic position}

The distribution by industry thus gives some illustration of the position of each language group in the labor market. In this section, I will focus on another important aspect, namely socioeconomic position. Due to their previously dominating position both in administration and economy, one widespread prejudice seems to be that Swedish speakers mainly belong to higher social and socioeconomic groups. The figures in Table 3 show that in the country as a whole this is evidently not true. The proportion of upper-level civil servants is only somewhat higher among Swedish speakers, and the distributions are generally very much the same for both language groups. The 
smaller proportion employed in manufacturing among Swedish speakers, which we could observe above, now corresponds with a smaller proportion in blue-collar jobs.

Table 3. The distribution by socioeconomic position of the economically active population in Finland 1995 for Finnish speakers and Swedish speakers.

\begin{tabular}{lccccccc}
\hline Finland 1995 & \multicolumn{7}{c}{ Civil servants } \\
\hline & Farmers & Employers & $\begin{array}{c}\text { Upper- } \\
\text { level }\end{array}$ & $\begin{array}{c}\text { Lower- } \\
\text { level }\end{array}$ & $\begin{array}{c}\text { Blue- } \\
\text { collar }\end{array}$ & Other & Total \\
\hline Finnish speakers & 4.5 & 8.7 & 18.1 & 34.6 & 32.7 & 1.4 & 100 \\
Swedish speakers & 6.7 & 9.4 & 21.2 & 35.0 & 25.4 & 2.2 & 100
\end{tabular}

\section{Swedish and bilingual municipalities 1970 and 1995}

Finnish speakers

$\begin{array}{llllllll}1970 & 1.1 & 4.5 & 10.9 & 34.9 & 48.2 & 0.4 & 100 \\ 1995 & 0.4 & 6.1 & 25.1 & 39.1 & 28.4 & 0.9 & 100\end{array}$

Swedish speakers

\begin{tabular}{rrrrrrrr}
1970 & 17.7 & 6.3 & 10.8 & 30.9 & 33.8 & 0.5 & 100 \\
1995 & 7.2 & 9.3 & 20.6 & 34.9 & 25.8 & 2.2 & 100 \\
\hline
\end{tabular}

Restricting the analysis to the main settlement area of the Swedish speakers changes the picture dramatically. In correspondence with the results in the previous section, there are very few Finnish-speaking farmers. The situation in 1970 also clearly illustrates the consequences of industrialization in the bilingual municipalities. Finnishspeaking blue-collar workers moved in, while the number of Swedish speakers going into manufacturing was rather low.

Great structural changes occurred up to 1995 . We can also see that, within the unilingual Swedish and bilingual municipalities, the proportion of upper-level civil servants is even higher among Finnish speakers than among Swedish speakers. In one way, however, this is a statistical illusion induced by between-group differences in the geographical distribution. In order to illustrate this, I have made a more detailed classification by region and distinguished between urban and rural municipalities (Table 4). 
Table 4. The distribution by socioeconomic position of the economically active population in 1995 for Finnish speakers and Swedish speakers. Unilingual Swedish and bilingual municipalities in different regions.

\begin{tabular}{llccccccc}
\hline & & \multicolumn{7}{c}{ Civil servants } \\
& & Farmers & Employers & $\begin{array}{c}\text { Upper- } \\
\text { level }\end{array}$ & $\begin{array}{c}\text { Lower- } \\
\text { level }\end{array}$ & $\begin{array}{c}\text { Blue- } \\
\text { collar }\end{array}$ & Other & Population \\
\hline Metropolitan & $\mathrm{Fi}$ & 0,1 & 5.7 & 28.1 & 40.5 & 24.7 & 0.9 & 355,165 \\
Area & $\mathrm{Sw}$ & 0.5 & 7.1 & 35.6 & 40.5 & 15.0 & 1.4 & 26,067 \\
Uusimaa, & $\mathrm{Fi}$ & 0.3 & 7.0 & 15.8 & 34.2 & 42.0 & 0.7 & 12,202 \\
Urban & $\mathrm{Sw}$ & 2.9 & 9.4 & 15.0 & 36.9 & 34.3 & 1.5 & 12,890 \\
Uusimaa, & $\mathrm{Fi}$ & 2.5 & 8.5 & 17.2 & 35.4 & 35.3 & 1.2 & 33,954 \\
Rural & $\mathrm{Sw}$ & 9.0 & 10.6 & 15.8 & 33.5 & 28.7 & 2.3 & 14,644 \\
Turku & $\mathrm{Fi}$ & 0.3 & 6.8 & 19.3 & 36.3 & 36.5 & 0.8 & 61,123 \\
(incl. Pargas) & $\mathrm{Sw}$ & 1.5 & 6.5 & 32.2 & 38.3 & 20.1 & 1.5 & 5,644 \\
Turunmaa & $\mathrm{Fi}$ & 9.4 & 10.7 & 9.8 & 28.2 & 39.6 & 2.3 & 1,282 \\
& $\mathrm{Sw}$ & 12.5 & 12.4 & 10.0 & 28.6 & 33.4 & 3.1 & 3,268 \\
Åland & $\mathrm{Fi}$ & 2.7 & 7.6 & 14.8 & 37.0 & 34.4 & 3.5 & 633 \\
& $\mathrm{Sw}$ & 6.5 & 10.0 & 13.9 & 35.6 & 30.3 & 3.7 & 10,737 \\
Pohjanmaa, & $\mathrm{Fi}$ & 0.7 & 7.0 & 16.7 & 35.3 & 39.4 & 0.8 & 33,341 \\
Urban & $\mathrm{Sw}$ & 7.9 & 9.2 & 18.8 & 35.1 & 27.0 & 1.9 & 21,630 \\
Pohjanmaa, & $\mathrm{Fi}$ & 10.3 & 8.8 & 10.3 & 29.4 & 38.7 & 2.5 & 1,666 \\
Rural & $\mathrm{Sw}$ & 20.6 & 11.4 & 9.9 & 24.9 & 29.7 & 3.5 & 15,687 \\
\hline
\end{tabular}

A general conclusion from Table 4 would be that regional differences are more profound than language group differences. Farmers are still Swedish speaking, however, and correspondingly, the relative proportion of blue-collar workers is higher among the Finnish speakers. The proportions of both upper- and lower-level civil servants are very much the same, with two exceptions. In both the Metropolitan Area and Turku, the proportions of upper-level civil servants are clearly higher among the Swedish speakers. In both regions about one-third of the economically active Swedish speakers are upper-level civil servants.

\section{Labor force participation and unemployment}

So far I have only focused on the economically active population. One evident expansion is to study whether there are differences with respect to the labor force participation and unemployment of the Swedish-speaking population on the Finnish labor market. Together with Saarela I have focused on this in some recent papers (Saarela and Finnäs 2002a; 2002b; 2003). 
According to data from 1990, 1995 and 1998, years which represent both an economic boom, a deep recession and an upswing, the activity in both language groups is very much the same. Table 5, which gives the proportions of employed and unemployed of the total population aged 20-64 years, shows that there are no signs of systematic differences between the two language groups. In a more detailed analysis we also took several background variables into account in a logistic regression model for the participation rate. However, the results with respect to language groups remained practically unchanged.

Table 5. Labor force participation rate in 1990, 1995 and 1998. Persons aged 2064 by language group and region. Percent.

\begin{tabular}{lcccccc}
\hline \multirow{2}{*}{ Region* } & \multicolumn{2}{c}{$\mathbf{1 9 9 0}$} & \multicolumn{2}{c}{$\mathbf{1 9 9 5}$} & \multicolumn{2}{c}{$\mathbf{1 9 9 8}$} \\
& Swe & Fin & Swe & Fin & Swe & Fin \\
\hline Uusimaa & 80.4 & 82.7 & 77.4 & 77.6 & 78.9 & 80.7 \\
Itä-Uusimaa & 80.0 & 82.2 & 79.0 & 79.5 & 81.1 & 80.8 \\
Varsinais-Suomi & 76.3 & 77.7 & 74.9 & 75.1 & 75.4 & 76.4 \\
Pohjanmaa & 79.8 & 80.1 & 78.6 & 77.1 & 80.0 & 78.3 \\
Keski-Pohjanmaa & 76.2 & 76.8 & 76.3 & 74.3 & 78.2 & 75.9 \\
Aland & 83.5 & 80.0 & 81.3 & 80.5 & 81.5 & 81.5 \\
Total & 80.0 & 81.7 & 78.1 & 78.2 & 79.7 & 79.9 \\
\hline
\end{tabular}

*These regions are presented according to the new administrative classification from 1997

However, when turning to success on the labor market, i.e. when we studied whether the individuals manage to find jobs or not, systematic differences between the language groups were found. For each year and each region the unemployment rate was clearly lower among Swedish speakers (Table 6). We also investigated the extent to which these differences could be explained by sociodemographic factors, and thus included a great number of covariates such as age, gender, type of family, previous industry and level of education, as well as language structure and industrial structure of the place of residence. In spite of our attempts, we did not manage to reduce much of the difference. Consequently, our conclusion was that the underlying reasons must be sought in factors not present in any existing register data set. We believe that one explanation may be that individual bilingualism is in general more widespread among the Swedish speakers. This may act in favor of them when searching for a job and also make their relative position on the labor market stronger. Unfortunately, explicit data on individual bilingualism does not exist. 
Table 6. Unemployment rate in 1990, 1995 and 1998. Persons aged 20-64 by language group and region. Percent.

\begin{tabular}{lrrrrrr}
\hline \multirow{2}{*}{ Region } & \multicolumn{2}{c}{$\mathbf{1 9 9 0}$} & \multicolumn{2}{c}{$\mathbf{1 9 9 5}$} & \multicolumn{2}{c}{$\mathbf{1 9 9 8}$} \\
& Swe & Fin & Swe & Fin & Swe & \multicolumn{1}{c}{ Fin } \\
\hline Uusimaa & 1.4 & 1.9 & 11.3 & 15.3 & 8.0 & 9.5 \\
Itä-Uusimaa & 2.1 & 3.7 & 12.1 & 16.5 & 8.2 & 11.6 \\
Varsinais-Suomi & 3.2 & 5.9 & 11.7 & 19.2 & 9.0 & 15.8 \\
Pohjanmaa & 4.0 & 5.5 & 11.8 & 18.0 & 8.1 & 14.1 \\
Keski-Pohjanmaa & 4.0 & 8.2 & 15.5 & 23.9 & 11.1 & 18.9 \\
Alland & 1.5 & 5.3 & 6.3 & 11.6 & 2.9 & 7.0 \\
Total & 2.5 & 2.8 & 11.2 & 16.2 & 7.7 & 10.8 \\
\hline
\end{tabular}

Recently, we have also studied another aspect related to labor market performance, namely retirement at a very early age (Saarela and Finnäs, 2002c). We were thus not interested in participation in 'standard' early retirement programs, which were introduced especially for persons at high working ages during the period of economic recession. We focused on persons aged 30-49. At this age retirement almost inevitably implies that a person will be receiving a disability pension.

Table 7. Predicted probability of very early retirement by language group and gender in Finland 1970-95. Standardized for age, education, socioeconomic position, industry, family status, region and period.

\begin{tabular}{lcc}
\hline Language & Males & Females \\
\hline Finnish & 0,036 & 0,030 \\
Swedish & 0,025 & 0,028 \\
\hline
\end{tabular}

Our analysis showed that disability retirement is clearly less common among Swedish speakers than among Finnish speakers (Table 7). This difference can also not be explained by the sociodemographic composition of the populations. The difference is larger among males. In that sense the results are in accordance with previous findings about the differences in mortality (Valkonen, Martelin and Rimpelä 1990; Valkonen et al.1992; Koskinen 1994; Martelin 1994; Finnäs, 1986). The life expectancy of Swedish-speaking males is about 2.5 years longer than the corresponding one for Finnishspeaking males, while the difference among females is about one year.

\section{Conclusions}

One evident result from the present study is that the position of the Swedish-speaking population differs from many other ethnic minority groups. It is well integrated in society, and has a strong position on the labor market. The Swedish speakers represent all industries and can be found in different socioeconomic positions. Generally, 
differences between regions are bigger than between the language groups. Any comparison, therefore, depends to a great extent on the regional divisions used.

Due to its size, regional distribution and history, it has been argued that the Swedishspeaking population lives in closer social networks than the Finnish speakers (see e.g. Saarela and Finnäs, 2002a), and that this may affect several aspects of life. It has been shown that marital stability is higher among Swedish speakers (Finnäs, 1997), and there are reasons to believe that this may also explain some of the difference in mortality (Hyyppä and Mäki 1997, 2001). Social factors may also be one possible reason for differences in retirement rates.

Despite the Swedish-speaking population being a minority in numbers, the most interesting scientific approach in my opinion is not to analyze it from a minority perspective. Instead one should in this context use language as an indicator to distinguish two subpopulations with different lifestyles. There seem to exist small but distinct differences between the two language groups with respect to social behavior and cultural life. It is, however, very difficult to distinguish subpopulations with respect to lifestyle, especially when using register data. In this sense, the language groups in Finland offer an interesting opportunity to investigate potential effects of 'soft' variables on different demographic behavior. Such studies cannot give definite answers, but they can rule out a great number of hypothetical factors and thus give important insights into the possible causal mechanisms. 


\section{References}

Becker, G. 1957. The Economics of Discrimination. University of Chicago Press, Chicago.

Borjas, G. 1993. The International Mobility of Immigrants. Journal of Labor Economics, 11, pp. $113-135$.

Borjas, G. 1994. Immigrant Skills and Ethnic Spillovers. Journal of Population Economics, 7 , pp. $99-118$.

Brenner, R. and N.M. Kiefer. 1981. The Economic of the Diaspora: Discrimination and Occupational Structure. Economic Development and Cultural Change, 29, pp. 517-533.

Chiswick, B. R. 1977. Sons of Immigrants: Are They at an earnings Disadvantage? American Economic Review, 67, pp. 288-325.

Chiswick, B. R. 1978. The Effect of Americanization on the Earnings of Foreign-born Men. Journal of Political Economy, 86, pp. 897-919.

Chiswick, B.R. 1983a. An Analysis of the Earnings and Employment of Asian-American Men. Journal of Labor Economics 1, pp. 197-214.

Chiswick, B.R. 1983b. The Earnings and Human Capital of American Jews. The Journal of Human Resources 18, pp. 313-336.

Drinkwater, S. J. and N.C. O'Leary. 1997. Unemployment in Wales: Does Language Matter? Regional Studies, 31, pp. 581-591.

Finnäs, F. 1997. Social Integration, Heterogeneity, and Divorce: The Case of the Swedishspeaking Population in Finland. Acta Sociologica, 40, pp. 263-277.

Hyyppä, M. T. and J. Mäki. 1997. Suomenruotsalaisen väestön hyvä terveys ja työkyky "säästävät" miljardeja. Suomen Lääkärilehti, 52, pp. 3237-3240.

Hyyppä, M. T. and J. Mäki. 2001. Individual-level Relationships between Social Capital and Self-rated Health in a Bilingual Community. Preventive Medicine, 32, pp. 148-155.

Koskinen, S. 1994. Origin of Regional Differences in Mortality from Ischaemic Heart Disease in Finland. Doctoral dissertation. Research Reports, No. 41. Jyväskylä: STAKES, National Research and Development Centre for Welfare and Health.

Martelin, T. 1994. Differential Mortality at Older Ages. Doctoral dissertation. Publications of the Finnish Demographic Society, No. 16. Helsinki.

Saarela, J. and F. Finnäs. 2002a. Ethnicity and Unemployment in Finland. Research Note. Ethnic Studies Review, 25, (1), 26-37.

Saarela, J. and F. Finnäs. 2002b. Unemployment and Native Language: The Finnish Case. The Journal of Socio-Economics, forthcoming.

Saarela, J. and Finnäs, F. 2002c. Language-group Differences in Very Early Retirement in Finland. Demographic Research, 7, (3), pp. 49-65. Available from: http://www.demographic-research.org.

Saarela, J. and F. Finnäs. 2003. Can the Low Unemployment Rate of Swedish-speakers in Finland be Attributed to Language-group and Industrial Structure? In: Essays on Labour Market Outcomes in the Bilingual Area of Finland, edited by Jan Saarela. Department of Economics and statistics, Åbo Akademi University. Doctoral dissertation.

Sowell, T. 1981. Markets and Minorities. Oxford: Basil Blackwell.

Valkonen, T., T. Martelin, and A. Rimpelä. 1990. Eriarvoisuus kuoleman edessä. Research Reports, No. 172. Helsinki: Statistics Finland.

Valkonen, T., T. Martelin, A. Rimpelä, V. Notkola, and S. Savela. 1992. Sosioekonomiset kuolleisuuserot 1981-90. SVT Väestö, No. 8. Helsinki: Statistics Finland. 